\title{
A CORPUS-BASED CONTRASTIVE STUDY OF EXPERIENCER VERBS IN ENGLISH AND SERBIAN: SOME IMPLICATIONS FOR THE STRUCTURE OF VP**
}

The aim of this paper is twofold. First, it reports on a parallel corpus study of experiencer verbs in English and Serbian and offers a contrastive description of this class of verbs. This investigation reveals two important observations: (i) a number of Serbian equivalents of English verbs with PP complements require oblique case-marked bare NP complements, (ii) the association between P-heads of these PP complements in English and their Serbian equivalents is not random (i.e. certain Ps in English correlate with certain Ps and/or oblique cases in Serbian). Understanding the potential theoretical significance of these observations is the second goal of the paper. The non-random link between English Ps and their Serbian counterparts speaks in favor of them having a semantic contribution, which goes against Neeleman's (1997) analysis of Ps in PP complements as having no semantic contribution due to the fact that they LF incorporate into the verb. Neeleman's (1997) account also fails to generalize to Serbian because oblique-cased bare NP complements exhibit syntactic characteristics of arguments. It is argued that the link between oblique-cased bare NP and PP complements speaks in favor of the functional/semantic equivalence along the lines of Caha $(2009,2013)$.

Key words: PP complements, experiencer verbs, parallel corpus, adjuncts, arguments, complements, English, Serbian.

\section{INTRODUCTION}

Experiencer verbs, or verbs that trigger entailments about emotional states of one of their arguments (Dowty 1991), are still a hotly debated subject in

\footnotetext{
* pedjakovacevic90@gmail.com

${ }^{* *}$ This paper was presented at the conference English Language and Anglophone Literatures Today (ELALT) 5, which took place at the University of Novi Sad (Faculty of Philosophy ) on March 9, 2019. The work on this paper was supported by Project No. 178002 of the Ministry of Education, Science and Technological Development of the Republic of Serbia.
} 
linguistics as evidenced by numerous recent books and papers tackling precisely this topic (Landau 2010, Alexiadou \& Iordachioaia 2014, Alexiadou 2016; Alexiadou 2018; Cheung \& Larson 2015; Fabregas \& Marin 2015; Hartshorne et al. 2016, among many others). The reason they are still the topic of linguistic debates is because they pose challenges to some of the most well-established linguistic theories, from Baker's (1988) Uniform Theta Assignment Hypothesis (UTAH) to theories in the domain of case and aspect. In English, as well as various other languages, they are quite well-described even though not completely understood. Comprehensive formal descriptions of English experiencer verbs including exhaustive lists and categorizations are, nonetheless, available (cf. Levin 1994), which is why investigations of this class of verbs are greatly facilitated.

In Serbian, experiencer verbs are still an uncharted territory, at least from the perspective of formal approaches. Several descriptive studies of these verbs, both in Serbian and in Croatian, have appeared recently (cf. Oraić 2008; Šaravanja 2011; inter alia). Some of these studies looked at specific verbs or specific subclasses of experiencer verbs (Arsenijević 2006, 2015). Others focused on some aspects of their syntax such as clausal complements (Oraić Rabušić 2016) or instrumental and dative NP complements (Brač and Oraić Rabušić 2016; Daković 2016). The most comprehensive studies of these verbs such as Milenković (2017) and Strbac (2006) come from the functionalist framework so the classifications and descriptions that they provide are not so informative and user-friendly from the perspective of formal approaches.

This paper is part of a larger study of the syntax and semantics of Serbian experiencer verbs from the generative perspective. The general goal of this paper will be to present a comparative overview of English and Serbian experiencer verbs based on a parallel corpus study of Serbian translations of The Harry Potter series and the Lord of the Rings trilogy. A more specific aim is to offer a classification of the Serbian data in line with established cross-linguistic classifications (cf. Belletti and Rizzi 1988; Landau 2010) as adapted for English by Levin (1994). As will be shown, the attempt to adapt Levin's (1994) classification to Serbian faces a number of challenges. The one that will be taken up here concerns the status of oblique case-marked NPs that often appear as counterparts of English PP complements (1).

(1) a. Tom marveled at the painting

b. Tom se divio slici

Tom SE marvel painting.dat

'Tom marveled at the painting' 
The status of these PPs in English is not particularly well-understood either and there have not been many attempts to offer a principled treatment of these elements (however, see Pesetsky 1994; Neeleman 1997). Thus, this paper will, indirectly, shed some light on their status in English by providing a comparative perspective.

It will be observed that PP complements of English experiencer verbs have two kinds of equivalents in Serbian: PPs and oblique-cased bare NPs. Moreover, the choice of one of these two options as well as the choice of a particular $\mathrm{P}$ or particular oblique case as an equivalent of a given $\mathrm{P}$ in English is not random, and interesting patterns can be observed in this regard. Next, it will be shown that at least oblique case-marked bare NPs in Serbian behave like arguments given the limited number of tests that can be used to tease these two categories apart. On the basis of these facts, the existence of Neeleman's (1997) category of PP complements will be called into question in favor of a simpler division between arguments and adjuncts where arguments can also be realized as PPs or obliquecased bare NPs. Finally, it will be suggested that these issues could be better handled drawing on Caha's $(2009,2013)$ implementation of the intuition about the functional and semantic equivalence of cases and prepositions.

\section{THEORETICAL BACKGROUND}

The literature on experiencer verbs is too extensive to be summarized here. Therefore, I will limit myself to providing a very general overview of those accounts that are relevant to any study of experiencer verbs as well as those works that pertain to the particular topic that I want to address here, i.e. the status of obligatory PPs and oblique-cased bare NPs with these verbs. The intense focus on experiencer verbs in the literature was sparked by the formulation of UTAH (Baker 1988). The idea behind this proposal is that there is a one-to-one mapping between syntactic positions in which elements are merged and thematic roles that they receive from the verb. Experiencer verbs represent a challenge for this theory because with these verbs the experiencer argument can appear in various syntactic configurations (2).

(2) a. John fears snakes

b. Snakes frighten John

c. Snakes appeal to John 
As shown in (2), the experiencer argument can occur in the subject position, in the object position and inside a PP complement.

Instead of taking these examples as a direct refutation of UTAH, Belletti and Rizzi (1988) argued that the experiencer argument does not actually have the same role with all of these verbs. The evidence for their analysis comes from atypical binding patterns that are observed with experiencer verbs in Italian. Namely, in Italian, the experiencer in the object position can bind a reflexive contained inside the subject NP, but a proper name in the object position with a verb of a different class cannot do so (3).

(3) a. Questi pettegolezzi su di se preoccupano Gianni piu di ogni altra cosa. 'These rumors about himself worry John more than anything else'

b. *Questi pettegolezzi su di se descrivono Gianni meglio di ogni biografia ufficiale.

'These rumors about himself describe John better than official biography'

Belletti and Rizzi (1988) take the contrast in (3) as evidence in favor of the idea that the surface word order with object experiencers is derived by movement from an underlying structure in which the experiencer actually c-commands the theme. If that is the case, Belletti and Rizzi (1988) argue, experiencer verbs have a syntactic structure that is different from those of other verbs, which makes it possible to maintain UTAH in the face of these apparent counterexamples. Belletti and Rizzi's (1988) analysis has been called into question by a number of authors (Pesetsky 1994, Landau 2010, among many others), but it is, nonetheless, extremely important because it represents the first powerful articulation of the idea that experiencer verbs do not falsify UTAH. The intuition that Belletti and Rizzi (1988) implement will be assumed here, too, although I will not commit myself to all the details of their analysis.

Focusing on the research question of the status of obligatory PPs (and oblique-cased bare NPs) with some experiencer verbs, there are two influential approaches. The first approach comes from Pesetsky's (1994) work on the so-called cascade structures. Pesetsky (1994) is concerned with the status of the obligatory PP with experiencer verbs such as the one in (4).

(4) Peter worried about his future. 
The obligatoriness of this PP precludes a simple analysis in which it represents nothing but an adjunct. On the other hand, the available theoretical apparatus has no room to explain the transmission of case and the thematic role from the verb to the DP inside the PP. Pesetsky (1994) proposes a cascade structure in which the PP represents a continuation of the VP, thus, making the VP structure 'deeper'. The most immediate empirical advantage of cascades is the possibility of accounting for examples such as (5).

(5) a. Sue spoke to these people ${ }_{i}$ about each other's friends in Bill's house.

b. John spoke to Mary about these people ${ }_{i}$ in each other ${ }_{i}^{\prime}$ s houses on Tuesday.

c. Sue gave books to these people $e_{i}$ on each other's birthdays.

(Pesetsky 1994: 172)

The problem with the examples in (5) is that the linear precedence seems to translate into hierarchy and c-command as the NP people binds the reciprocal to its right in every sentence. These facts are problematic for any standard theory of binding relations. Pesetsky (1994) proposes a cascade structure in (6) as a way of capturing these data.

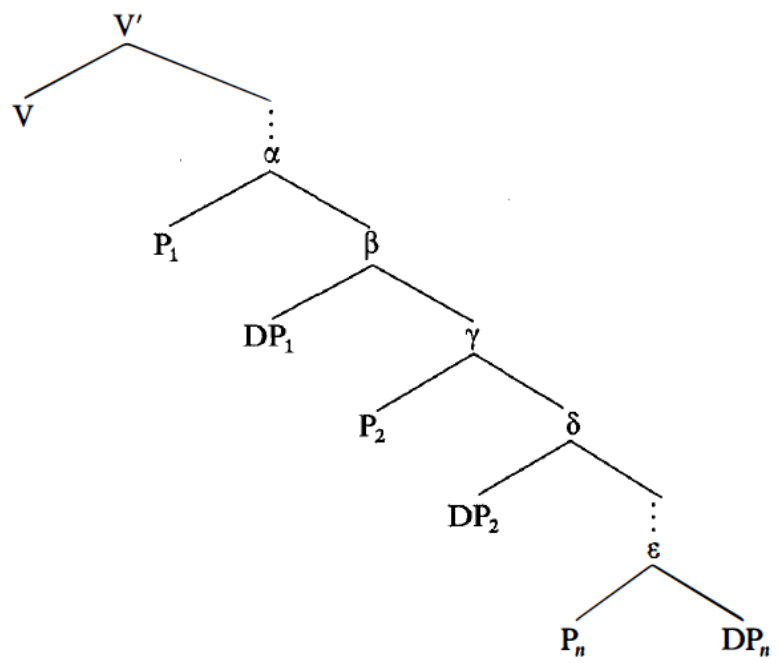

(Pesetsky 1994: 174) 
By treating PP complements as extensions of the VP deeper down, Pesetsky (1994) provides a systematic explanation for these puzzles in the domain of binding. One should note, on the basis of Pesetsky's (1994) examples in (5), that the notion of 'complements' becomes much looser under this approach and extends deep into the territory of traditional adjuncts.

A different approach to obligatory PPs comes from Neeleman (1997). He proposes a tripartite division into argument PPs, complement PPs and adjunct PPs as illustrated in the example in (7) from Dutch.

(7) a. Dat de held op het laatste moment gered werd

adjunct that the hero at the last moment saved was

b. Dat ik door de polder zou willen afraden argument that I through the polder would want to-advise-against

c. Dat Jan op zijn geluk vertrouwt

complement that John on his luck trusts

(Neeleman 1997: 91)

The highlighted PP in (7a) is a typical temporal adjunct, which can be omitted without consequences. In (7b), the PP is the object of the main verb, and it can also be analyzed as a reduced DP. Nonetheless, the PP has a compositional, predictable denotation. Finally, in (7c), the PP does not have a typical PP denotation and it is an obligatory part of the construction.

Neeleman (1997) argues that the PP in (7c) should be analyzed as PP complement, but such an analysis requires a more thorough syntactic explanation. In particular, it raises the question of the transmission of a thematic role, and the role of the preposition in the interpretation of the sentence. Drawing on Chomsky's (1995) dismissal of D-Structure with the requirement that theta assignment has to take place at D-Structure, Neeleman (1997) suggests that the PP is active in overt syntax but at LF, the $\mathrm{P}$ head incorporates into the verb, and the verb, then, theta marks the DP that is left in the complement of the PP.

Neeleman's (1997) approach certainly has an advantage in the fact that it does not depart from the mainstream views in such a radical way as Pesetsky's (1994) proposal. However, it has no way of accounting for the problematic binding facts that are captured by Pesetsky (1994). Also, Neeleman's (1997) account treats the $\mathrm{P}$ head inside the PP as semantically vacuous, and it provides no mechanism that could deal with the presence of oblique-cased bare NPs in similar contexts in other languages. 


\section{DATA: CORPUS EXPLORATION}

In the exploratory part of this work, I carried out a parallel corpus study using sentence-aligned parallel corpora of the Lord of the Rings and Harry Potter series and their Serbian translations (compiled by A. Kavgić). The sub-corpus consisting of the original texts of Lord of the Rings Trilogy contained 455,125, while the sub-corpus that was made up of the Harry Potter series contained $1,084,170$ words. In total, the English part of the parallel corpus had more than 1.5 million words. Therefore, the corpus was sizable enough to satisfy the needs of a study of this kind.

It should be emphasized that this is an exploratory corpus study rather than a hypothesis-driven one. Consequently, the data will be presented as illustrations of important patterns that have been observed without the accompanying quantitative reports and statistical tests, which would not add anything substantial to the exposition in this paper.

The goal was to achieve a thorough formal description of Serbian data using Levin's (1994) list and classification of experiencer verbs as a starting point. In the second phase, after I complied the list of Serbian equivalents of English experiencer verbs, I carried out the same procedure from the opposite direction starting from Serbian verbal lexemes and looking at English equivalents. This second phase was useful because some Serbian verbs were frequently used as equivalents of adjectival phrases in English.

The reason why Levin's (1994) classification was selected as the starting point is twofold. First, it is the most comprehensive classification of psych verbs available in the literature. Other influential classifications, such as the one provided in Belletti and Rizzi (1994) and adopted with minor modifications in Pesetsky (1994) and Landau (2010), divide the category of experiencer verbs into three classes leaving out an entire class that is included into Levin's (1994) classification. Second, Levin's (1994) classification is the only one I know of that provides extensive, one is tempted to say exhaustive, lists of experiencer verbs belonging to each class.

Levin (1994) classifies experiencer verbs into four classes building on Belletti \& Rizzi's (1998) original three-way classification. She distinguishes between admire-type (8a), amuse-type (8b), marvel-type (8c) and appeal-type (8d) verbs. 
(8) a. Tom admires his professors

b. The professor amused the students

c. Lucy marveled at the artwork

d. The professor's jokes appealed to the students

Admire-type verbs realize the experiencer argument as the subject while the stimulus argument is realized as the object. Amuse-type verbs exhibit the opposite pattern, whereby the experiencer is in the object position while the stimulus is the subject. With marvel-type verbs, the experiencer is in the subject position, once again, but the stimulus is realized in the form of a PP. Finally, appeal-type verbs realize the experiencer in the form of a PP while the subject position is filled by the stimulus participant. In total, Levin (1994) lists 349 different verbal lexemes and classifies them into the four classes she identified.

I searched the parallel corpora for each verb from Levin's (1994) list and recorded the ways in which they were translated. For the purposes of this paper, I will focus only on the instances in which a lexical verb was used to translate a particular verb in English. The Serbian data were, then, organized according to the formal properties of the verbs that were used as the basis for Levin's (1994) classification. The criteria of interest were the syntactic position of the experiencer and the stimulus participant as either the subject or the object of the sentence and the morphosyntactic realizations of these expressions as NP/DPs or PPs.

The presentation of the Serbian data will, thus, be organized following Levin's (1994) classification. The source of the example will be given in brackets (HP for Harry Potter and LOTR for Lord of the Rings).

The examples in (9) show the most common patterns.

(9) a. oni vole mir i tišinu i dobro obdelavanu zemlju admire-type they love peace.acc and quiet.acc and well-tilled.acc earth.acc "they love peace and quiet and good tilled earth" (LOTR)

b. Mora da ih je nekako uznemirio amuse-type must DA them.acc aux.cl somehow upset He must've upset them somehow (HP)

c. lično mi se ne dopada njihova stopa smrtnosti appeal-type personally me.dat.cl SE not like their.nom rate.nom mortality.gen I don't personally fancy the mortality rate (HP)

d. što mi je najviše prijalo $i$ iskoristio sam to what me.dat.cl aux.cl most appeal.prt.neut and use.prt.masc aux.cl.1sg 
that

it was most convenient and I used it (HP)

e. Pipin se čudio njegovoj snazi marvel-type

Pippin SE marvel his.dat strength.dat

"Pippin marvelled at his strength" (LOTR)

f. Čudio se zbog toga, jer je bio skoro zaboravio sunce wonder SE because that.gen because aux.cl was almost forgot sun.acc He wondered at it, for he had almost forgotten about the Sun (LOTR)

g. mi se ne plašimo njih!

We SE neg fear them.gen

"we do not fear them!"

h. Krajnje je vreme da tvoja baka nauči da se ponosi svojim unukom extreme aux.cl time that your grandma learn DA SE pride refl.poss.inst grandson.inst

It's high time your grandmother learned to be proud of the grandson (HP)

i. ne brinući o tome što ih pedesetak ljudi posmatra, Hari je poljubi

not worrying about that which them.acc.cl fiftyish people look Harry her.acc kiss

without worrying about the fact that fifty people were watching, Harry kissed her (HP)

The data in (9) show that the situation in Serbian is more complicated than in English because there are subject experiencer verbs which take a PP stimulus like in English (9f, 9i) and those that take a genitive (9g), dative (9e) or instrumental (9h) marked bare NP stimuli. These data raise some important questions. The first question concerns the status of different PP and oblique-cased bare NP complements in Serbian and whether there are differences in the status of these two types of complements. Secondly, one might wonder about the significance of the correlations between specific Ps that appear as heads of these complements in English and their Serbian equivalents. Quite frequently directional Ps such as AT or TO in English have the equivalents in the form of dative bare NPs, which often mark directionality in Serbian (9e,9d). In other contexts, one finds these directional English Ps translated as PPs headed by prepositions with similar semantics such as NA ('at/to') (10). Similarly, English Ps that encode the meaning of source such as OF or FROM tend to be translated either as genitive bare NPs (11a) or PPs with 
similar prepositions such as OD ('of/from') (11b). These questions will be taken up in the next section. kontrolišuću kletvu

Očigledno je to bila njegova reakcija na loše izvedenu

Apparently AUX that was his reaction to poorly performed controlling curse

'He has clearly reacted to a poorly performed Imperius Curse' (HP)
a. Toga se i bojao
that.gen SE and fear
'He had been afraid of that' (HP)
b. Lucijusov strah od gospodara koga godinama nije bilo
Lucius's fear of master.gen who years AUX.neg was
'Lucius's fear of a master who had been gone for years' (HP)

\section{OBLIQUE-CASED BARE NP STIMULI: ADJUNCTS, ARGUMENTS OR COMPLEMENTS}

This section will present an argument that the Serbian data presented in Section 3 in parallel with the English equivalents cannot be accounted for on Neeleman's (1997) approach relying on the idea about PP complements and LF incorporation of the $\mathrm{P}$ head. The reason for this is that his account faces difficulties when it comes to explaining the existence of oblique-cased bare NPs in these positions. Furthermore, Neeleman (1997) assumes that the P head of the PP complement does not have any semantic contribution, but such an approach is contradicted by the correlations between the $\mathrm{P}$ that appears as a complement of one verb in English and the case form and/or P that appears in its Serbian counterpart. These correlations reveal that there is a significant semantic contribution of the relevant $\mathrm{P} /$ case form.

Before I examine the Serbian data in light of Neeleman's (1997) analysis, I want to ward off the idea that the PPs and oblique-cased bare NPs that occur with Serbian experiencer verbs in the examples (9-11) are actually adjuncts. Such a view would hardly get off the ground, especially in the case of bare NPs elements because one would have to assume that they represent an additional class of bare NP adjuncts. Standard accounts of bare NP adjuncts (cf. Larson 1985) usually rely on the special locative or temporal semantics of the nouns that can appear inside those elements, which is responsible for independently assigning case and thematic 
role to these NPs. However, the NPs that appear as oblique case-marked stimuli are clearly not of that sort (i.e. they do not normally refer to locations and times).

Applying syntactic tests that are used to tease apart adjuncts and arguments to the bare NPs that can be found with experiencer verbs in Serbian, one can see that they pattern with arguments rather than adjuncts. Bošković (2008) points out that the movement of the NP complement out of an adjunct results in a total ungrammaticality while the same movement out of an argument results in a degraded but marginally acceptable sentence.

a. *Moga djeda $\mathrm{i}_{\mathrm{j}}$ je trčao [šumom $\mathrm{t}_{\mathrm{i}}$ ]. my.gen grandfather.gen is run forest.instr

'He ran through the forest of my grandfather.'

b. ??Moga djeda $a_{i}$ je volio [šumu $t_{i}$ ]. my.gen grandfather.gen is loved forest.acc 'He loved the forest of my grandfather.' (Bošković 2018)

Extracting the complement of a dative-marked stimulus (13) yields results that are much closer to (12b) than (12a).

$$
\begin{aligned}
& \text { ??Mog dede se divila šumi } \\
& \text { my.gen grandfather.gen SE marvel forest.dat } \\
& \text { 'She marveled at my grandfather's forest' }
\end{aligned}
$$

With genitive stimuli (14), complement extractions are much worse but this is probably due to the fact that movement across elements that match the element that moves in all its features (case is especially important) is banned across the board as argued by (Kuno 1980, 2003, inter alia for Japanese and Kovačević 2014 for Serbian).

$$
\begin{aligned}
& \text { *Mog dede se bojala šume } \\
& \text { My.gen grandfather.gen SE scare forst.gen } \\
& \text { 'She was afraid of my grandfather's forest' }
\end{aligned}
$$

One should also rule out the possibility that these genitive and dative marked bare NPs are predicates. This can be seen from the fact that they are fully referential as shown, for instance, by the fact that they can be realized as pronouns (15). 

a. Jovan se njoj divi
John.nom SE her.dat marvel
'John admires her/John marvels at her'
b. Jovan se nje plaši
John.nom SE her.gen sacre
'John is afraid of her'

Of course, having shown that these bare NPs should not be treated as either adjuncts or predicates, one should consider the possibility that they are PP complements in the sense of Neeleman (1997). The problem with applying Neeleman's (1997) analysis to these elements has several dimensions. There is the conceptual issue reflected in the fact that such an analysis would require assuming the existence of a null $\mathrm{P}$ that is responsible for assigning case to its NP complement. This null $\mathrm{P}$ would then incorporate into the verb at LF. In a sense, in order to apply Neeleman's (1997) analysis to these examples one would have to subscribe to the idea that there is a covert $\mathrm{P}$ that undergoes covert LF movement with these elements.

Even if one were prepared to accept such a proposition, one would be at pains to find evidence to support it while there is important evidence to the contrary. For instance, genitive and dative bare NPs that appear with experiencer verbs can cliticize (16).

$$
\begin{aligned}
& \text { a. Mi ih se ne plašimo } \\
& \text { we them.dat.cl SE neg fear.1pl } \\
& \text { 'We are not afraid of them' } \\
& \text { b. On mu se divi }
\end{aligned}
$$

He him.dat.cl SE marvel

'He admires him/He marvels at him'

This fact speaks against the null-P analysis of these elements because PPs do not allow cliticization. Abels (2003) derives the ban on clitics that originate inside PPs from the impossibility of moving the complement of a phasal head due to the interplay of PIC and anti-locality and the necessity of moving the clitics to the second position in Serbian. Milićev \& Bešlin (2019) use Abels's (2003) account to explain why instrumental case does not produce a clitic form in Serbian by suggesting that instrumental case actually appears inside a PP headed by a null $\mathrm{P}$ (see M\&B's paper for additional evidence that instrumental NPs are actually PPs with a null head). Therefore, at least for genitive and dative bare NPs with 
experiencer verbs, it is safe to assume that they do not involve a null $\mathrm{P}$ contrary to what is predicted by Neeleman's (1997) analysis applied to Serbian.

Another problem associated with Neeleman's (1997) account is that it does not leave any room for a semantic contribution of the $\mathrm{P}$ head inside a PP complement. The reason why this is a problem is not apparent when looking only at English or Dutch. In fact, Neeleman (1997) uses the relative semantic vacuity of prepositions inside PP complements to distinguish them from prepositions in adjunct or argument PPs, which retain clear locative, temporal, causal, etc. semantics. However, assuming that these prepositions have no semantic contribution implies that the reason why, say, AT appears together with the verb marvel is purely a matter of (diachronic) coincidence and not something that reflects the actual interpretation of a sentence containing this verb and this preposition. Such a view, then, has nothing to say about the fact that a Serbian verb such as diviti se that means roughly the same as marvel requires a dative casemarked bare NP as its complement event though both a PP headed by AT and a dative case-marked NP typically involve directional semantics in these two languages. Similarly, a PP headed by AT that appears in adjectival phrases such as angry at has its equivalent in another expression of directionality in Serbian in the phrase besan $n a$, with the preposition $n a$ also expressing directional semantics as in (17).

$$
\begin{aligned}
& \text { Milan cilja na Petra } \\
& \text { Milan aims at Peter.acc } \\
& \text { 'Milan is aiming at Peter' }
\end{aligned}
$$

I would propose that these correlations are not accidental and that these Ps and case forms do have a semantic contribution. It is not my aim to make that semantic contribution explicit in this paper. Such an account will be left for further research. I will, however, propose a framework for an account of that sort. Caha's $(2009,2013)$ recent work on the Nanosyntax of case and prepositions seems like a promising line of thinking to couch an analysis of these phenomena in. The reason for this is that this framework treats case morphology and prepositions as realizations of the same abstract concepts arranged in a hierarchy (18).

$$
\text { nom }<\text { acc }<\text { gen }<\text { dat }<\text { ins }<\text { com }
$$

(Caha 2009: 33)

In Caha's work, these abstract meanings are arranged in a hierarchy or nested structure that is available on top of every NP/DP. The higher layers of 
structure are 'peeled off' through movement operations that strand higher portions of the hierarchy in order to reveal lower ones. The NP/DP itself finally moves successive-cyclically to the highest projection in the hierarchy it can reach.

Languages differ in the height of NP/DP movement. In some languages, the NP/DP can move all the way up to comitative, and such languages will have that case realized in the form of a suffix. In others, NP/DPs will be able to move only until, say, accusative, and all the meanings that are higher in the containment hierarchy will be realized in the form of prepositions. In Serbian, the NP will be able to move all the way up to instrumental and all these meanings would be realized by means of case suffixes. By contrast, English DPs can only move to accusative, and all the other cases are realized by means of prepositions. The lexical properties of the verb select the case they need for their argument.

\section{CONCLUSIONS AND FURTHER RESEARCH}

Summing up, the aim of this paper was to offer a comparative description of Serbian and English experiencer verbs with a special focus on the status of obligatory PPs and oblique-cased NP/DPs. The data were drawn from a parallel corpus of Serbian translations of The Harry Potter series and The Lord of the Rings based on Levin's (1994) list and classification of experiencer verbs in English. The central observation was that Serbian experiencer verbs can take complements in the form of oblique-cased bare NPs as well as PPs. These complements appear as the equivalents of English obligatory PPs in a non-random manner (i.e. certain prepositions in English tend to be associated with similar prepositions and cases with a similar default meaning in Serbian).

These observations were taken as a basis of a critique of Neeleman's (1997) analysis of PP complements relying on the idea about LF incorporation of the preposition into the verb. This analysis is built on the idea that Ps that appear inside PP complements are semantically completely vacuous. This assumption is problematic because it would fail to capture the systematic links between the prepositions that appear in these constructions in English and their Serbian counterparts in the form of prepositions and cases with similar meanings. Moreover, Neeleman's (1997) idea fails to generalize to oblique-cased bare NPs in Serbian because it predicts the presence of a covert $\mathrm{P}$ that (covertly) incorporates into the verb at LF, which is both conceptually problematic and empirically contradicted by the fact that genitive and dative complements cliticize quite freely. PPs, on the other hand, always resist cliticization, and in fact, the lack of cliticization with instrumentals is a major argument in favor of treating instrumentals as PPs with a 
null P (Milićev \& Bešlin 2019). The proposal in this paper was that oblique-cased bare NPs with experiencer verbs should be analyzed as arguments. Finally, it was suggested that Caha's $(2009,2013)$ approach to case could provide a basis for an account that would make explicit the connection between English prepositions and Serbian oblique cases and prepositions.

Predrag Kovačević

KORPUSNA KONTRASTIVNA STUDIJA PSIHOLOŠKIH GLAGOLA U ENGLESKOM I SRPSKOM: NEKE IMPLIKACIJE ZA STRUKTURU GLAGOLSKE SINTAGME

\section{Rezime}

Rad ima dva glavna cilja. Prvi je da prikaže rezultate istraživanja psiholoških glagola u engleskom i srpskom zasnovanog na paralelnom korpusu i da ponudi kontrastivni opis ove klase glagola. Navode se dva glavna zapažanja (i) jedan broj srpskih ekvivalenata engleskih glagola sa dopunom u vidu predloške sintagme zahteva dopunu u vidu imeničke sintagme $u$ kosom padežu, (ii) veza između predloga u predloškim sintagmama na engleskom i njihovih srpskih ekvivalenata nije nasumična (tj. određeni predlozi u engleskom koreliraju sa određenim predlozima i/ili kosim padežima u srpskom). Drugi cilj rada je razumevanje teorijskih implikacija ovih zapažanja. Korelacija između engleskih predloga i njihovih srpskih parnjaka govori u prilog tome da oni imaju semantički značaj, što je nasuprot Nelemanove (1997) analize ovih predloga kao elemenata bez semantičkog doprinosa koji se na nivou interpretacije inkorporiraju u glagol. Nelemanov (1997) pristup se ne može generalizovati na imeničke sintagme u kosim padežima u srpskom jeziku jer one ispoljavaju osobine argumenata. Iznosi se tvrdnja da se veza između kosih padeža i predloga u predloškim dopunama može razumeti iz perspektive Cahinog $(2009,2013)$ pristupa po kom se uspostavlja funkcionalna i semantička veza između predloga i padeža.

Ključne reči: dopune u vidu predloških sintagmi, psihološki glagoli, paralelni korpus, adjunkti, argumenti, dopune, engleski, srpski.

\section{REFERENCES}

Abels, K. (2003). Successive cyclicity, anti-locality, and adposition stranding. (Doctoral dissertation). University of Connecticut.

Alexiadou, A.-Iordăchioaia, G. (2014). The psych causative alternation. Lingua, 148, 53-79.

Alexiadou, A. (2016). English psych verbs and the causative alternation: A case study in the history of English. Questions and Answers in Linguistics, 3(2), $1-13$. 
Alexiadou, A. (2018). -Able adjectives and the syntax of psych verbs. Glossa: a journal of general linguistics, 3(1).

Arsenijević, N. (2015). Glagoli strahovanja i njihove dopune. In: Grković Major, J. -Ružić, V. (eds.) (2015). Lingvističke sveske 10, Srpski jezik i njegova norma, Novi Sad: Filozofski fakultet, 176-192.

Arsenijević, N. (2006). O glagolima voleti i zaljubiti se. In: Piper, P. (ed.) (2006). Zbornik radova Kognitivnolingvistička proučavanja srpskog jezika. Beograd: SANU. 71-85.

Baker, M. C. (1988). Incorporation: A theory of grammatical function changing. Chicago: University of Chicago Press.

Belletti, A.-Rizzi, L. (1988). Psych-verbs and $\theta$-theory. Natural Language \& Linguistic Theory, 6(3), 291-352.

Birtić, M.-Brač, I. \& Runajić, S. (2017). The main features of the e-Glava online valency dictionary. In: Kosem, I.-Tiberius, C.-Jakubíček, J.-Kallas, M. J.Krek, S. \& Baisa V. (eds.) (2017). Electronic Lexicography in 21st Century. Proceedings of eLex 2017 Conference. Leiden: The Dutch Language Institute. 43-62.

Brač, I.-Oraić Rabušić, I. (2016). Određenje instrumentalne imenske skupine kao dopune u psiholoških glagola. Jezikoslovlje, 17(1-2.), 247-265.

Bošković, Ž. (2014). Now I'ma phase, now I'm not a phase: On the variability of phases with extraction and ellipsis. Linguistic inquiry, 45(1), 27-89.

Bošković, Ž. (2018). On movement out of moved elements, labels, and phases. Linguistic Inquiry, 49(2), 247-282.

Caha, P. (2009). The nanosyntax of case. (Doctoral dissertation). University of Tromso.

Caha, P. (2013). The jungle of the Czech local cases: Where semantics and morphology meet. In: Caha, P.-Schürcks, L.-Giannakidou, A. \& Etxeberria, U. (eds.) (2013). The nominal structure in Slavic and beyond. Berlin: Walter de Gruyter. 209-237.

Cheung, C. C. H.-Larson, R. K. (2015). Psych verbs in English and Mandarin. Natural Language \& Linguistic Theory, 33(1), 127-189.

Daković, S. (2016). Izražavanje psihičkih stanja u hrvatskom i poljskom jeziku strukture s dativnim argumentom. Fluminensia , 27(2), 161-173.

Dowty, D. (1991). Thematic proto-roles and argument selection. Language, 67(3), 547-619.

Fábregas, A.-Marín, R. (2015). Deriving individual-level and stage-level psych verbs in Spanish. The Linguistic Review, 32(2), 227-275. 
Grohmann, K. K. (2003). Prolific domains: On the anti-locality of movement dependencies. Amsterda: John Benjamins Publishing.

Hartshorne, J. K.-O’Donnell, T. J.-Sudo, Y.-Uruwashi, M.-Lee, M. \& Snedeker, J. (2016). Psych verbs, the linking problem, and the acquisition of language. Cognition, 157, 268-288.

Kovačević, P. (2014). A (Very) Minimal Syntax: On the Relationship of DP, Scrambling and Case. (MA Thesis). University of Novi Sad.

Larson, R. K. (1985). Bare-NP adverbs. Linguistic inquiry, 16(4), 595-621.

Levin, B. (1994). English verb classes and alternations: A preliminary investigation. Chicago: University of Chicago press.

Milenković, A. (2017). Semantička $i$ tvorbena analiza glagola kojima se označavaju osećanja u savremenom srpskom jeziku. (Doctoral dissertation). Univerzitet u Beogradu.

Milićev, T. -Bešlin, M. (2019). Instrumental case: why it is absent from the clitic system in Serbian/Croatian. In: Lopičić, V.-Mišić-Ilić, B. (eds.) (2019). Language, Literature, Theory. Niš: Faculty of Philosophy. 153-169.

Marelj, M. (2004). Middles and argument structure across languages. (Doctoral dissertation). Netherlands Graduate School of Linguistics.

Neeleman, A. D. (1997). PP-complements. Natural Language \& Linguistic Theory, 15(1), 89-137.

Oraić, I. (2008). Kako razvrstati glagole s elementom se u valencijskome rječniku hrvatskih glagola?. Rasprave Instituta za hrvatski jezik i jezikoslovlje, 34, 269-283.

Oraić Rabušić, I. (2016). Rečenice kao dopune uz psihološke glagole u hrvatskom jeziku. Fluminensia, 28(2), 71-86.

Pesetsky, D. M. (1994). Zero syntax: Experiencers and cascades. Boston: MIT press.

Samardžić, T. (2006). Reč se u argumentskoj strukturi ditranzitivnih glagola. Naučni sastanak slavista u Vukove dane, 35(1), 179-193.

Šaravanja, L. (2011). Argumentna struktura psiholoških glagola u hrvatskom jeziku. Suvremena lingvistika, 37(72), 241-258.

Štrbac, G. (2006). O valentnosti glagola emocionalnog sadržaja u srpskom jeziku. Zbornik Matice srpske za filologiju i lingvistiku, 49(2), 73-103. 